\title{
Comparative Appraisal of Insecticidal Operations Against Spruce Budworm in Quebec During Two Outbreaks
}

\section{J. R. Blais}

Laurentian Forest Research Centre

Canadian Forestry Service

Department of Fisheries and the Environment

Sainte-Foy, Quebec

\begin{abstract}
Large-scale aerial applications of chemical insecticides against spruce budworm (Choristoneura fumiferana (clem.)) took place in Quebec during two outbreaks, 1952-58 (Outbreak I) and 1970-75 and continuing (Outbreak II), in an effort to prevent extensive mortality of fir and spruce. During Outbreak I yearly treatment consisted of one application of DDT at $0.6 \mathrm{~kg} / \mathrm{ha}(8 \mathrm{oz}$./ac.); during Outbreak II it consisted of two applications of organophosphates and carbamates (mostly fenitrothion) for a total of $0.3 \mathrm{~kg} / \mathrm{ha}$ (4 oz./ac.). The effects of a single treatment were evident for two years in Outbreak I because of residual properties of DDT, while in Outbreak II, effects were evident only in the year of application. Reduction in budworm populations due to treatment was considerably greater during Outbreak I than during Outbreak II. Average foliage protection in the year of treatment and in the following year was $38 \%$ and $60 \%$ respectively in Outbreak I, while it was $15 \%$ and $0 \%$ in Outbreak II. Spray operations in any one treatment area were repeated after an interval of three or four years due to population build up in Outbreak I; continuously high populations necessitated yearly applications of insecticides in Outbreak II. It is suggested that the current spraying policy in Quebec should be reappraised in the light of conditions that prevail.
\end{abstract}

\section{Résumé}

Des pulvérisations aériennes d'insecticides chimiques contre la tordeuse des bourgeons de l'épinette (Choristoneura fumiferana (Clem.)\} furent pratiquées au Québec au cours de deux épidémies de 1952 à 58 (Epidémie I) et de 1970 à 75 et par la suite (Epidémie II) pour réduire les dégâts occasionnés par l'insecte. Lors de la première épidémie le traitement annuel consistait en une application de DDT au taux de $0.6 \mathrm{~kg} / \mathrm{ha}(8 \mathrm{oz}$./ac.); lors de la deuxième épidémie il consistait en deux applications d'organophosphates et de carbamates (surtout le fenitrothion) pour un total de $0.3 \mathrm{~kg} / \mathrm{ha}(4 \mathrm{oz} . / \mathrm{ac}$.). Les effets du traitement étaient évidents sur une période de deux ans au cours de l'Epidémie I, tandis que lors de I'Epidémie II, les effets n'apparaissaient que l'année d'application. La réduction des populations de l'insecte due au traitement étaie considérablement plus élevée lors de I'Epidémie I que lors de I'Epidémie II. La protection moyenne du feuillage l'année du traitement et l'année suivante était de $38 \%$ et de $60 \%$ pour l'Epidémie I, tandis qu'elle était de $15 \%$ et $0 \%$ pour l'Epidémie II. Les pulvérisations devaient être répétées à un intervalle de trois à quatre ans pour les secteurs traités à cause d'une recrudescence des populations au cours de l'Epidémie I; les populations élevées continues dans les secteurs traités exigeaient l'application d'insecticides à tous les ans au cours de l'Epidémie II. II est suggéré que la politique des arrosages contre la tordeuse au Québec mérite d'être réexaminée à la lumière des conditions existantes.

\section{Introduction}

Spruce budworm (Chorsitoneura fumiferana (Clem.)) outbreaks recur periodically in eastern Canada, and spruce-fir stands in Quebec are especially prone to attacks by this insect (Blais 1968). During the two recent occurrences (hereafter designated as Outbreak I and Outbreak II), aerial application of insecticides was resorted to in an attempt to reduce damage. Outbreak I began in western Quebec in 1939 and gradually spread eastward until it reached the Lower St. Lawrence in 1944 and Gaspé regions in 1946 (Brown 1970), when extensive tree mortality had already taken place in pulpwood stands in the western and central sectors of the province. To preserve the valuable spruce-fir stands in the Lower St. Lawrence and Gaspé regions from a similar fate, the Provincial Government decided to treat infested stands by aerial application of DDT. Treatment was applied on a very small scale in 1952 and 1953, then on a large scale from 1954 until 1958 when the outbreak collapsed (Blais and Martineau 1960). A remnant outbreak persisted for another four years in the Rimouski and Patapedia river watersheds; it ended in 1962 mainly as a result of three consecutive years of spraying operations (Blais 1963). Only the large-scale operations during the five-year period 1954-58 will be discussed with respect to Outbreak I. The small-scale, special-objective operations before and after this period are excluded from consideration.

After 1963 populations of the insect remained at an endemic level throughout the province. Another general infestation began in western Quebec in 1967 (Outbreak II) and spread rapidly eastward. By 1974 the outbreak covered $32,375,000$ ha (about 80 million ac.) encompassing practically all sprucefir stands in the province from the Ontario border to Anticosti Island. Once again an effort was made to reduce damage using chemical control. When spraying operations began in 1970, areas treated were confined to western Quebec, but as outbreaks developed eastward, operations took place in many regions of the province including the $\mathrm{Te}$ miscouata Region and parts of the Gaspé Peninsula. Outbreak II was still in progress at the time of writing, and an extensive chemical control program was planned for 1976. The infestation and control measures in Quebec may continue for some years. The report deals with results for only the first five years of treatment (1970-75).

During the past 25 years, changes have occurred in the operational aspects of the spraying programs against the budworm. This includes choice of insecticides, type of aircraft, navigation guidance systems, spraying equipment and application techniques. I will not review operational 
aspect in detail but will refer to them only insofar as they affect biological aspects of the control programs. There have also been changes in the target stage of budworm development. The larger larval stages (fourth to sixth instars) are more exposed and easier to hit with insecticides, but such mature larvae have already caused substantial defoliation. The earlier stages (second and third instar) are more difficult targets usually concealed in leaf mines or buds, but damage is minimal.

Most data for Outbreak I were obtained by the author in the 1950's, while data for Outbreak II were extracted from annual reports by the Quebec Department of Lands and Forests.

\section{Insecticides, Dosages and Timing of Operations}

From 1954 to 1958 , DDT was applied at the rate of $0.6 \mathrm{~kg} / \mathrm{ha}(8 \mathrm{oz} . / \mathrm{ac} .)^{1}{ }^{1}$ in one application per year; the timing of application varied according to budworm developmental stage, larval abundance, and the condition of the forest. Most stands responded well to treatment when applied to the fourth and early fifth-instar larvae exposed in the flaring shoot. Where past defoliation had been severe, greater emphasis was placed on saving the surviving buds and shoots and an attempt was made to spray early larval instars; where insect populations were moderate or low (less than 15 larvae par $46 \mathrm{~cm}$ (18 in.) branch tip) some defoliation could be tolerated and spraying could safely be delayed.

When spraying operations were resumed during Outbreak II, fenitrothion was the principal insecticide used. In 1970 and 1971, there was only one application of fenitrothion at $0.2 \mathrm{~kg} / \mathrm{ha}(3 \mathrm{oz} . / \mathrm{ac}$.$) ,$ aimed at fourth-instar budworm. From 1972 to 1975, two successive applications of the insecticides were made. In 1972 and 1973 most of the areas treated received a first application of fenitrothion at $0.2 \mathrm{~kg} / \mathrm{ha}(3 \mathrm{oz}$./ac.) as soon as secondinstar larvae had emerged, and $0.15 \mathrm{~kg} / \mathrm{ha}(2 \mathrm{oz} . /$ ac.) when surviving larvae were in the fourth instar. In 1974, although fenitrothion was used to treat over 1,619,000 ha (4 million ac.), Matacil and

1Imperial units were used throughout operations; metric conversions in the paper are not always exact.
Zectran were used to treat about 450,000 ha (1 million ac.) respectively. Most of the area treated with fenitrothion received two applications at 0.15 $\mathrm{kg} / \mathrm{ha}(2 \mathrm{oz} . / \mathrm{ac}$.) each time. Matacil and Zectran were applied at $0.05 \mathrm{~kg} / \mathrm{ha}(0.75 \mathrm{oz}$./ac.) for two applications. In 1975 there was a general insecticide shortage so phosphamidon was used as well as the other three insecticides. Dosages were the same as 1974 for fenitrothion, Matacil and Zectran, and phosphamidon was applied at 0.15 $\mathrm{kg} / \mathrm{ha}(2 \mathrm{oz}$./ac.). Again, the insecticides were applied twice and some combinations were used. In certain cases the same insecticide was used for the two applications, in others they differed. An important change was introduced in 1974 and continued in 1975 with respect to timing of application. First application took place very early, when $50 \%$ of the overwintered larvae had emerged; second application was aimed at the third instar. The reason for the early application was to hit the emerging budworm before they mined into buds.

\section{Spray Policy}

The area treated each year of operation in relation to the total outbreak area for both outbreaks is given in Table 1. It should be remembered that at time of treatment, Outbreak I in Quebec was continuous with an outbreak in northern New Brunswick and Maine; Outbreak II was continuous at first with an outbreak in eastern Ontario, and as it spread eastward it became continuous with the outbreak in New Brunswick and Maine. Areas under attack and areas treated for Quebec and New Brunswick for each year during Outbreak I are given in detail by Webb et al. (1961). For Outbreak II, areas under attack in Quebec and in adjoining provinces for each year after 1970 are reported by Martineau and Lavallée (1972), Lavallée and Benoit (1973) and Martineau et al. (1974, 1975, 1976). During both outbreaks only a fraction of the infested area was treated each year (Table 1). In 1954 and 1955 , stands were treated when they had sustained the loss of approximately three year's foliage and where destruction of the next year's foliage was indicated by high egg counts. From 1956 to 1958 , stands having sustained two successive years of severe defoliation and supporting

Table 1. Outbreak area, area treated, percentage outbreak area treated by year for two outbreaks in Quebec

\begin{tabular}{|c|c|c|c|c|c|c|}
\hline \multirow[b]{2}{*}{ Outbreak } & \multirow[b]{2}{*}{ Year } & \multicolumn{2}{|c|}{ Outbreak (Area) } & \multicolumn{2}{|c|}{ Area treated } & \multirow{2}{*}{$\begin{array}{c}\text { Percentage } \\
\text { of outbreak } \\
\text { area } \\
\text { treated }\end{array}$} \\
\hline & & acres & hectares & acres & hectares & \\
\hline $\mathbf{I} \ldots \ldots \ldots \ldots \ldots \ldots \ldots \ldots \ldots$ & $\begin{array}{l}1954 \\
1955 \\
1956 \\
1957 \\
1958\end{array}$ & $\begin{array}{r}8,384,000 \\
10,048,000 \\
9,920,000 \\
9,664,000 \\
2,368,000\end{array}$ & $\begin{array}{r}3,393,000 \\
4,066,000 \\
4,015,000 \\
3,911,000 \\
958,000\end{array}$ & $\begin{array}{r}318,000 \\
1,040,000 \\
442,000 \\
1,255,000 \\
797,000\end{array}$ & $\begin{array}{l}129,000 \\
421,000 \\
179,000 \\
508,000 \\
323,000\end{array}$ & $\begin{array}{r}4 \\
10 \\
4 \\
13 \\
34\end{array}$ \\
\hline II................... & $\begin{array}{l}1970 \\
1971 \\
1972 \\
1973 \\
1974 \\
1975\end{array}$ & $\begin{array}{r}6,000,000 \\
13,000,000 \\
25,700,000 \\
28,200,000 \\
79,600,000 \\
87,400,000\end{array}$ & $\begin{array}{r}2,428,000 \\
5,261,000 \\
10,401,000 \\
11,412,000 \\
32,214,000 \\
35,370,000\end{array}$ & $\begin{array}{r}29,000 \\
2,147,000 \\
1,879,000 \\
9,727,000 \\
6,345,000 \\
7,134,000\end{array}$ & $\begin{array}{r}12,000 \\
869,000 \\
760,000 \\
3,936,000 \\
2,568,000 \\
2,887,000\end{array}$ & $\begin{array}{c}0.5 \\
17 \\
7 \\
35 \\
8 \\
8\end{array}$ \\
\hline
\end{tabular}


high egg populations were included in the spray program (Blais et al. 1976). When spraying operations began in Outbreak II, the same spray policy as in 1956-58 was used. It soon became apparent however, that this policy was no longer valid, because the new insecticides at dosages used did not save trees when applied in the third year of severe attack; by this time tree vigour had declined to a point where treatment was not effective. After 1972, stands were generally treated in the second year of severe attack.

In Outbreak II practically all areas requiring protection according to this spray policy were treated until 1973, the year of the largest operation to date when $3,936,000$ ha (9.7 million ac.) or $35 \%$ of the infested territory was treated Table 1). From the beginning until 1973, the outbreak area increased fairly gradually, but in 1974 it tripled in size from $11,412,000$ ha (28 million ac.) to 32,214 ,000 ha (80 million ac.) Table 1). For the first time it was no longer possible to treat all stands requiring protection. That year, close to $11,000,000$ ha (28 million ac.) were in need of protection. Because of a world shortage of insecticides, coupled with the tremendous cost of treating such a large area, only $2,568,000$ ha ( 6.3 million ac.) could be treated. The outbreak had then reached such proportions that the Quebec Department of Lands and Forests was obliged to adopt new guidelines with respect to budworm control; regions having the highest balsam fir content and where the pulpwood industry is a mainstay would receive priority. Generally, once selected, these same regions would require treatment each year the outbreak persisted, while the remainder of attacked stands would be unprotected.

\section{Methods for Evaluating Operations}

The methods used to appraise yearly results of spraying operations during the two outbreaks have remained basically unchanged. Pre-spray and postspray budworm densities were assessed by tallying larvae or pupae on $46 \mathrm{~cm}$ (18 in.) branch tip samples cut by pole pruners from the mid-crown of balsam fir. The pre-spray population fix was obtained by counting mining second and thirdinstar larvae during Outbreak I and during Outbreak II until 1973. In 1974 and 1975, densities of overwintering second-instar larvae were assessed by using special emergence boxes; this technique tends to underestimate populations. The postspray population fix was obtained by counting pupae on branch tips during both outbreaks. Budworm egg densities were obtained by using the sequential sampling technique developed by Morris (1954). However, the method for measuring branch surface legg densities are related to branch surface) was modified during Outbreak II, and this tended to overestimate egg populations with respect to those of Outbreak I. Defoliation was assessed through extensive aerial surveys for both treated and untreated areas together with ground surveys involving closer examination of trees and branch tips for both outbreaks.

\section{Effects of Spraying on Spruce Budworm Populations}

Pre-spray population densities (second to third instar) were essentially the same for both outbreaks; although varying between localities and regions for any given year, they usually averaged between 20 and 30 per $46 \mathrm{~cm}$ (18 in.) branch tip (Table 2). There are two exceptions; in 1958 (last year of Outbreak I) pre-spray populations were well below 20, and in 1975 (Outbreak II) average pre-spray populations were very high, close to 60 per $46 \mathrm{~cm}$ (18 in.) branch tip.

Each year the effect of the current year's spray operations was determined by comparing 1) pupal densities and 2) degree of defoliation of the current year's growth for sprayed and adjacent unsprayed areas for both outbreaks (Table 2). In Outbreak I, the beneficial effects of the sprays, in addition to being felt the year of treatment persisted the year following. Therefore data for Outbreak I are given for currently treated sectors and for those treated the previous year. In contrast, for Outbreak II densities were reduced only in the year of treatment, and tended to approximate pretreatment levels the next year. Since populations were low in 1958, (collapse of Outbreak I), and because only a small area was treated in 1970 (Table 1), data for both years are excluded.

Average pupal densities per branch tip for all years in unsprayed areas for outbreaks I and II were 4.2 and 5.4 respectively (Table 2). However, there was a striking contrast between pupal densities in sprayed areas between the two outbreaks; the average pupal density per branch tip in the year of treatment was 0.5 and 4.0 for outbreaks I and II respectively. Since pre-spray densities were about the same in both outbreaks this indicates population reduction through spraying was about 8 times greater during Outbreak I than during Outbreak II. Further evidence of the greater efficacy of treatment in the 1950's compared with that of the 1970's is gained by comparing the per cent reductions in population densities due to treatment using Abbott's formula. This formula is based on data obtained from treated and untreated sectors, and permits an appraisal of mortality due to treatment alone by excluding mortality attributable to natural control factors. Average per cent reduction in budworm density due to treatment the year of application for Outbreak I was $88 \%$ and for Outbreak II it was $27 \%$ (Table 2). In Outbreak I the effects of treatment persisted into the following year when pupal populations were about $50 \%$ lower than in unsprayed areas. In Outbreak II pupal densities in the sprayed sectors were not much lower than those in the untreated sectors.

Egg-mass densities in Quebec varied considerably between years for sprayed and unsprayed localities during both outbreaks (Table 3). Egg density is shown to be lower during Outbreak I than during Outbreak II. However, the similarity in pre- (small larvae) and post-spray (pupae) populations, and in the average defoliation for untreated 
areas (Table 2) for both outbreaks would indicate budworm populations were much more similar than shown by the egg-mass density data. As mentioned earlier, the difference in egg density between the two outbreaks could be attributable, in part, to liberties that were taken with the sequenial egg counts during Outbreak II.

It is significant that in the year of treatment in the sprayed sector the mean egg density was two thirds less than in untreated sectors for Outbreak I, while mean egg densities did not differ greatly between sprayed and unsprayed localities for Outbreak II.

\section{Effects of Spraying on Foliage Protection}

The main purpose for applying insecticides is to kill enough budworm in time to save foliage. The success of a control program is measured by the amount of foliage saved since the repeated destruction of the current year's foliage results in tree mortality after four or five years. During Outbreak I, the average amount of the current year's foliage saved during the year of treatment was $38 \%$, but the beneficial effect of the treatment was even more pronounced the year following through a protracted effect when an average of $60 \%$ was saved. During Outbreak II, protection of the current year's foliage for five years of treatment varied, it was $0 \%$ for the poorest year (due partly to poor timing of application) and $45 \%$ for the best; the other three years averaged about $11 \%$, and the overall average was $15 \%$ (Table 2).

Tree physiologists have long recognized that the most recent foliage is most valuable to growth of conifers, and that this value decreases with age of foliage. Hardy and Dorais (1976) basing their calculations on Clark's (1961) studies on photosynthesis and respiration for balsam fir estimated that starting with the current foliage each of five consecutive years' foliage contributed $37,27,19$, 11 , and $6 \%$ to the productivity. Therefore for a twoyear period (year of treatment and year following), average productivity of foliage saved from one year's treatment for Outbreak I is equal to 46 or (38\% of $37+60 \%$ of $37+38 \%$ of 27 ) and for Outbreak II it is equal to 10 or $15 \%$ of $37+15 \%$ of 27). According to these calculations the average amount of foliage saved as a result of one year's treatment during Outbreak I had approximately five times the value of that during Outbreak II.

Table 2. Average number of insects per $46 \mathrm{~cm}$ (18 in.) branch at the time of pre- and post-spray surveys, per cent reduction in population, and per cent foliage saved by insecticidal treatment during two budworm outbreaks in Quebec

\begin{tabular}{|c|c|c|c|c|c|c|c|c|}
\hline Outbreak & Year & Treatment & $\begin{array}{l}\text { No. of } \\
\text { localities } \\
\text { sampled }\end{array}$ & $\begin{array}{l}\text { Ave. No. of } \\
\text { small larvae } \\
\text { (pre-spray) }\end{array}$ & $\begin{array}{c}\text { Av. No. of } \\
\text { pupae } \\
\text { (post-spray) }\end{array}$ & $\begin{array}{l}\text { \% reduction } \\
\text { in popula- } \\
\text { tion by } \\
\text { spraying }\left({ }^{1}\right)\end{array}$ & $\begin{array}{l}\text { Av. } \% \\
\text { defo- } \\
\text { liation }\end{array}$ & $\begin{array}{l}\% \text { current } \\
\text { foliage } \\
\text { saved by } \\
\text { spraying }\end{array}$ \\
\hline \multirow[t]{5}{*}{$\mathbf{I} \ldots \ldots \ldots$} & 1954 & $\begin{array}{l}\text { unsprayed } \\
\text { sprayed } 1954\end{array}$ & - & 27 & $\overline{0.4}$ & $\overline{90}$ & $\begin{array}{l}97 \\
52\end{array}$ & $\overline{45}$ \\
\hline & 1955 & $\begin{array}{l}\text { unsprayed } \\
\text { sprayed } 1955 \\
\text { sprayed } 1954\end{array}$ & $\begin{array}{r}98 \\
108 \\
19\end{array}$ & $\begin{array}{r}27 \\
29 \\
5\end{array}$ & $\begin{array}{l}2.8 \\
0.3 \\
1.8\end{array}$ & $\begin{array}{l}\overline{89} \\
36\end{array}$ & $\begin{array}{l}69 \\
26 \\
12\end{array}$ & $\begin{array}{l}\overline{43} \\
57\end{array}$ \\
\hline & 1956 & $\begin{array}{l}\text { unsprayed } \\
\text { sprayed } 1956 \\
\text { sprayed } 1955\end{array}$ & $\begin{array}{r}112 \\
52 \\
54\end{array}$ & $\begin{array}{r}24 \\
22 \\
3\end{array}$ & $\begin{array}{l}6.5 \\
0.5 \\
2.3\end{array}$ & $\begin{array}{l}\overline{92} \\
65\end{array}$ & $\begin{array}{l}84 \\
37 \\
17\end{array}$ & $\begin{array}{l}\overline{47} \\
67\end{array}$ \\
\hline & 1957 & $\begin{array}{l}\text { unsprayed } \\
\text { sprayed } 1957 \\
\text { sprayed } 1956\end{array}$ & $\begin{array}{l}88 \\
59 \\
15\end{array}$ & $\begin{array}{r}34 \\
32 \\
9\end{array}$ & $\begin{array}{l}3.2 \\
0.6 \\
1.4\end{array}$ & $\begin{array}{l}\overline{81} \\
56\end{array}$ & $\begin{array}{l}76 \\
58 \\
33\end{array}$ & $\begin{array}{l}\overline{18} \\
43\end{array}$ \\
\hline & Mean & $\begin{array}{l}\text { unsprayed } \\
\text { year sprayed } \\
\text { year after }\end{array}$ & & $\begin{array}{r}28 \\
28 \\
6\end{array}$ & $\begin{array}{l}4.2 \\
0.5 \\
1.8\end{array}$ & $\begin{array}{l}88 \\
52 \\
\end{array}$ & $\begin{array}{l}82 \\
43 \\
21 \\
\end{array}$ & $\begin{array}{l}38 \\
60 \\
\end{array}$ \\
\hline \multirow[t]{6}{*}{ II........ } & 1971 & $\begin{array}{l}\text { unsprayed } \\
\text { sprayed }\end{array}$ & $\begin{array}{r}8 \\
104\end{array}$ & $\begin{array}{l}17 \\
20\end{array}$ & $\begin{array}{l}4.5 \\
2.8\end{array}$ & $\overline{32}$ & $\begin{array}{l}90 \\
98\end{array}$ & $\overline{0}$ \\
\hline & 1972 & $\begin{array}{l}\text { unsprayed } \\
\text { sprayed }\end{array}$ & $\begin{array}{r}41 \\
100\end{array}$ & $\begin{array}{l}30 \\
25\end{array}$ & $\begin{array}{l}5.7 \\
3.3\end{array}$ & $\overline{31}$ & $\begin{array}{l}88 \\
43\end{array}$ & $\overline{45}$ \\
\hline & $1973\left({ }^{2}\right)$ & $\begin{array}{l}\text { unsprayed } \\
\text { sprayed }\end{array}$ & $\begin{array}{r}84 \\
260\end{array}$ & $\begin{array}{l}21 \\
25\end{array}$ & $\begin{array}{l}4.7 \\
3.6\end{array}$ & $\overline{36}$ & $\begin{array}{l}54 \\
41\end{array}$ & $\overline{13}$ \\
\hline & 1974 & $\begin{array}{l}\text { unsprayed } \\
\text { sprayed }\end{array}$ & $\begin{array}{r}72 \\
286\end{array}$ & $\begin{array}{l}23^{(3)} \\
26^{(3)}\end{array}$ & $\begin{array}{l}7.0 \\
5.8\end{array}$ & $\overline{27}$ & $\begin{array}{l}68 \\
59\end{array}$ & $\overline{9}$ \\
\hline & 1975 & $\begin{array}{l}\text { unsprayed } \\
\text { sprayed }\end{array}$ & $\begin{array}{l}113 \\
414\end{array}$ & $\begin{array}{l}37^{(3)} \\
34^{(3)}\end{array}$ & $\begin{array}{l}5.2 \\
4.4\end{array}$ & $\overline{8}$ & $\begin{array}{l}82 \\
72 \\
\end{array}$ & $\overline{10}$ \\
\hline & Mean & $\begin{array}{l}\text { unsprayed } \\
\text { sprayed }\end{array}$ & & $\begin{array}{l}26 \\
26\end{array}$ & $\begin{array}{l}5.4 \\
4.0\end{array}$ & 27 & $\begin{array}{l}74 \\
63\end{array}$ & 15 \\
\hline
\end{tabular}

(1)Using Abbott's formula

(2)Does not: Include data for Temiscouata or Gaspé regions

(3)Pre-spray populations are underestimated because of method used in obtaining data (see text) 


\section{Summary and Discussion}

The synopsis of the main differences between treatments and between results of treatments for outbreaks I and II is:

1- Yearly treatment consisted in one application of DDT at $0.6 \mathrm{~kg} / \mathrm{ha}(8 \mathrm{oz}$./ac.) for Outbreak I; it consisted in two applications of organophosphates (mostly fenitrothion) for a total of $0.3 \mathrm{~kg} / \mathrm{ha}(4 \mathrm{oz}$./ac.) for Outbreak II.

2- Foliage protection and tree survival was satisfactory during Outbreak I even when first treatment was delayed until the third or fourth year of severe defoliation; in contrast, during Outbreak II, results were unsatisfactory when first treatment was applied later than the second year of severe defoliation.

3- Beneficial effects of treatment were felt for two years in Outbreak I, and for one year in Outbreak II.

4- Budworm populations were reduced during the year of treatment and the following year by $88 \%$ and $52 \%$ respectively for Outbreak I, and by $27 \%$ and $0 \%$ for Outbreak II.

5- Budworm survival rate (pupal tally) after treatment was 8 times lower in Outbreak I than in Outbreak II.
6- Egg populations were two-thirds lower in the treated than in the untreated sectors for Outbreak I, while there was no difference in number of eggs between treated and untreated sectors for Outbreak II.

7- Average foliage protection during the year of treatment and the year following was $38 \%$ and $60 \%$ for Outbreak I, while it was $15 \%$ and $0 \%$ for Outbreak II.

8- Index of photosynthetic capacity of foliage saved for a 2 year period (year of treatment and year following) from one treatment was 46 for Outbreak I, and 10 for Outbreak II.

When the spraying program was initiated in the 1950's the managers' aim was to keep the forests alive during the outbreak period. This hope was realized, and when the outbreak came to an end in 1958 through the combined action of natural control factors and DDT, most affected stands were still alive (Blais and Martineau 1960). The success of that spray program raised expectations of success with the current program. The situation in the 1970's however, differs significantly from that of the 1950's. Rates of budworm kill and foliage protection are lower in the current program. The two consecutive years of foliage proteo

Table 3. Densities of spruce budworm egg masses in sprayed and untreated sectors of Quebec forests during two outbreaks

\begin{tabular}{|c|c|c|c|c|c|c|}
\hline \multirow{2}{*}{$\frac{\text { Outbreak }}{\text { I. } \ldots \ldots \ldots \ldots \ldots \ldots \ldots \ldots \ldots \ldots \ldots \ldots}$} & \multirow{2}{*}{$\begin{array}{c}\text { Year } \\
1953\end{array}$} & \multirow{2}{*}{$\begin{array}{l}\text { Treatment } \\
\text { unsprayed }\end{array}$} & \multirow{2}{*}{$\begin{array}{c}\begin{array}{c}\text { No. of } \\
\text { localities }\end{array} \\
400\end{array}$} & \multicolumn{3}{|c|}{$\begin{array}{l}\text { Egg masses per } 9 \mathrm{~m}^{2}\left(100 \mathrm{ft}^{2}\right) \\
\text { of branch-surface }\end{array}$} \\
\hline & & & & 318 & & \\
\hline & 1954 & $\begin{array}{l}\text { unsprayed } \\
\text { sprayed } 1954\end{array}$ & $\begin{array}{r}526 \\
80\end{array}$ & 158 & 52 & \\
\hline & 1955 & $\begin{array}{l}\text { unsprayed } \\
\text { sprayed } 1955 \\
\text { sprayed } 1954\end{array}$ & $\begin{array}{r}469 \\
130 \\
57\end{array}$ & 246 & 63 & 105 \\
\hline & 1956 & $\begin{array}{l}\text { unsprayed } \\
\text { sprayed } 1956 \\
\text { sprayed } 1955\end{array}$ & $\begin{array}{r}446 \\
56 \\
110\end{array}$ & 289 & 195 & 206 \\
\hline & 1957 & $\begin{array}{l}\text { unsprayed } \\
\text { sprayed } 1957 \\
\text { sprayed } 1956\end{array}$ & $\begin{array}{r}445 \\
141 \\
41\end{array}$ & 87 & 52 & 13 \\
\hline . & Average & $\begin{array}{l}\text { unsprayed } \\
\text { year sprayed } \\
\text { year after }\end{array}$ & & 220 & 75 & 108 \\
\hline \multirow[t]{7}{*}{ II $\ldots \ldots \ldots \ldots \ldots \ldots \ldots \ldots \ldots$} & 1970 & $\begin{array}{l}\text { unsprayed } \\
\text { sprayed }\end{array}$ & $\begin{array}{l}375 \\
101\end{array}$ & 737 & 1,295 & \\
\hline & 1971 & $\begin{array}{l}\text { unsprayed } \\
\text { sprayed }\end{array}$ & $\begin{array}{l}313 \\
101\end{array}$ & 807 & 847 & \\
\hline & 1972 & $\begin{array}{l}\text { unsprayed } \\
\text { sprayed }\end{array}$ & $\begin{array}{r}397 \\
73\end{array}$ & 552 & 542 & \\
\hline & 1973 & $\begin{array}{l}\text { unsprayed } \\
\text { sprayed }\end{array}$ & $\begin{array}{l}547 \\
267\end{array}$ & 1,096 & 666 & \\
\hline & 1974 & $\begin{array}{l}\text { unsprayed } \\
\text { sprayed }\end{array}$ & $\begin{array}{r}1,124 \\
212\end{array}$ & 1,664 & 2,163 & \\
\hline & 1975 & $\begin{array}{l}\text { unsprayed } \\
\text { sprayed }\end{array}$ & $\begin{array}{r}1,345 \\
726\end{array}$ & 918 & 888 & $\therefore$ \\
\hline & Average & $\begin{array}{l}\text { unsprayed } \\
\text { year sprayed }\end{array}$ & 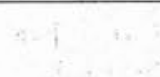 & 1,086 & 1,038 & \\
\hline
\end{tabular}


tion resulting from one application of DDT provided treated stands with renewed vigour. Usually there was a lapse of three to four years before stands treated once required a second treatment. For the five years of operation in Quebec during Outbreak $1,84 \%$ of the net area was sprayed once and only $16 \%$ received two applications (Webb et al. 1961). In Outbreak II the small amounts of foliage saved and the high budworm survival require that treatment be applied sooner with respect to number of years ot attack, and usually be repeated yearly.

The differences in results obtained through chemical control measures between these two outbreaks in Quebec may be attributable to operational practices and to inherent characteristics of the outbreaks. The area of infestation during the years of treatment under review for Outbreak II was much more extensive than for Outbreak I, and this could have provided a greater source of reinvasion of treated areas through the immigration of moths from untreated areas. It is probable, however, that differences in results of treatment between the two outbreaks are due mostly to types of insecticides used, timing of application, and rates of application. Because of its persistent qualities, DDT, in addition to reducing the target population by 80 to $90 \%$ at time of application, may have killed larvae of the second generation dispersing from egg masses in mid summer (Macdonald 1963). The organophosphates that have replaced DDT are applied at low dosages and kill fewer budworm. Furthermore, these insecticides degrade rapidly and appear to have no residual effect on the next budworm generation.

DDT was withdrawn from use against budworm in 1968, and public opinion may not condone a return to this very effective insecticide for budworm control because of its reputation as being dangerous to the environment. However, the current dosages of fenitrothion against budworm could be increased within regulatory limits. A total application of $0.4 \mathrm{~kg} / \mathrm{ha}$ (6 oz./ac.) meets regulations but in Quebec, in an effort to minimize side effects to the ecosystem, only $0.3 \mathrm{~kg} / \mathrm{ha}$ (4 oz./ac.) has been used. The current control program aims at keeping trees alive in treated areas during the outbreak, and since tree protection may prolong outbreaks, spraying may be necessary for many years, as in New Brunswick (Blais 1974). The current budworm control program in Quebec, because it has given poorer results than the preceding one is not, till now, necessarily a failure; there are pulpwood stands alive to-day that would be dying or dead had there been no treatment. However, some forest entomologists in Quebec fear that if the outbreak continues, much of the forest designated for protection will be lost because insufficient foliage is saved through conventional treatment. By 1976, close to $\$ 40$ million, will have been invested during the current outbreak in Quebec in an effort to control budworm damage. Are these expenditures justified or is management fighting a losing battle? This question is certainly valid and it is imperative that the current spraying policy be reappraised at this time.

This paper should not be construed as a plea for a return to DDT, or for an increase in the dosage of insecticides now applied in Quebec. My aim is simply to review facts that, hopefully, will aid the assessment of the present state of the outbreak and of the forest condition. Only in the light of a critical appraisal of the situation and of its economic and social implications will it be possible to determine whether the current spraying policy should be continued or modified. Furthermore, these data pertain only to Quebec; the results should not be extrapolated as necessarily valid in other provinces and states with a budworm problem.

\section{References}

Blais, J. R. 1963. Control of a spruce budworm outbreak in Quebec through aerial spraying operations. Can. Ent. 95: 821-827.

1968. Regional variation in susceptibility of eastern North American forests to budworm attack based on history of outbreaks. Forest. Chron. 44: 17-23.

1974. The policy of keeping trees alive via spray operations may hasten the recurrence of spruce budworm outbreaks. Forest. Chron. 50: 19-21.

and R. Martineau. 1960. A recent spruce budworm outbreak in the Lower St. Lawrence and Gaspé with reference to aerial spraying operations. Forest. Chron. 36: 209-224.

and P. Benoit. 1976. Aerial control against the spruce budworm in Quebec. In M. L. Prebble (ed.) Aerial control of forest insects in Canada. Can. Forest. Serv. Dep. Publ. 113-125.

Brown, C. E. 1970. A cartographic representation of spruce budworm Choristoneura fumiferana (Clem.), infestation in eastern Canada, 1909-1966. Can. Forest. Serv. Rep. 1263.

Clark, J. 1961. Photosynthesis and respiration in white spruce and balsam fir. N.Y. State Univ., College Forest. Tech. Publ. 85.

Hardy, Y. J., and L. G. Dorais. 1976. Elaboration d'une carte, présentant le risque de retrouver de la mortalité dans les forêts de sapin baumier, Abies balsamea (Mill.), attaquées par la tordeuse des bourgeons de l'épinette, Choristoneura fumiferana (Clem.). Can. J. Forest Res. (In Press).

Lavallée, A., and P. Benoit. 1973. Insectes et maladies des arbres, Région de Québec - 1972. Forêt-Conserv. (supplément) 38 .

Macdonald, D. R. 1963. The analysis of survival and reproduction in the sprayed area. In the dynamics of epidemic spruce budworm populations. Edited by R. F. Morris. Mem. Entomol. Soc. Can. 31: 130-170.

Martineau, R., and A. Lavallée. 1972. Insectes et maladies des arbres, Région de Québec - 1971. Forêt-Conserv. (supplément) 38 .

Insectes et maladies des arbres, Région de Québec 1974. 1973. Forêt-Conserv. (supplément) 40.

Insectes et maladies des arbres, Région de Québec 1975. 1974. Forêt-Conserv. (supplément) 41.

Insectes et maladies des arbres, Région de Québec 1975. Forêt-Conserv. (supplément) 42.

Morris, R. F. 1954. A sequential sampling technique for spruce budworm egg surveys. Can. J. Zool. 32: 302-313.

Webb, F. E., J. R. Blais, and R. W. Nash. 1961. A cartographic history of spruce budworm outbreaks and aerial forest spraying in the Atlantic region of North America, 19491959. Can. Entomol. 93: 360-379. 